\title{
CONSUMERS' CHOICE OF MARKET OUTLETS FOR FRESH LEAFY VEGETABLES AMONG RURAL AND URBAN HOUSEHOLDS IN FEDERAL CAPITAL TERRITORY, NIGERIA
}

\author{
Ebukiba Elizabeth Samuel, Adamu Sunday Malgwi* \\ Department of Agricultural Economics, University of Abuja, Nigeria \\ *E-mail: adamusmalgwi@yahoo.com
}

\begin{abstract}
This study examined consumers' choice of market outlets for fresh leafy vegetables among rural and urban households in Federal Capital Territory, Nigeria. Stratified, purposive and convenience sampling techniques was used to select, 713 households (363 urban households and 350 rural households) in four Area Council in FCT. Primary data were collected using well-structured questionnaire, descriptive and inferential statistics were used to analyse the data. The result revealed that local/ open air-markets and (road side for rural households) while (Farm gate for urban household) were the most preferred retail outlets in rural and urban households, respectively. The multinomial logit model showed that age, Gender (Sex), Education level, household size, Distance to the nearest market outlet, weekly expenditure of consumers has significant relationship with the probability of choosing farm gate, home/kiosk, road side and hawking as market outlets for fresh leafy vegetables among rural households as well as urban households with exception of personal income. Consumers have to be properly educated on the importance of various market outlets for fresh leafy vegetables in the study area and strategies that would expand fresh leafy vegetables varietal diversity at the farm gate outlets would enhance their choice among rural households. Also, policies that would enhance investment in research and production of certified seeds for various fresh leafy vegetables to farmers for use by relevant government organization(s) among both rural and urban households in the study area.
\end{abstract}

\section{KEY WORDS}

Consumers' choice, market outlets, fresh leafy vegetable, multinomial logit, households.

There has been an increasing demand for production and consumption of fresh vegetables in Northern Nigeria. Abuja, with its cosmopolitan nature, has attracted a great diversity of LVs from all over the country to its markets, as different communities have always had their traditional specialties, and the demand for same seems to have reemerged. Consumption of vegetables is very common in the diets of people. In Africa, vegetables are part of the daily diets and are found especially in soups and sauces accompanied by carbohydrate staples (Smith \& Eyzaguirre, 2007). The recommended vegetables per day per person by World Health Organization (2006) are about $130 \mathrm{~kg}$ per day per person. Due to its significance, it generates income to a large proportion of the rural households (Efa \& Tura 2018). About 30,000 edible plants are found throughout the world, 7,000 of which are grown or collected as food (Natarajan, 2002). According to Smith and Eyzaguirre (2007), about 3,000 species of these plants have been commercialized with only about 20 species consumed on large scale. Leafy Vegetables (LV) are increasingly recognized as possible contributors of both micronutrients and bioactive compounds to the diets of populations in Africa. The African continent is rich of vegetable species including amaranthus which are among the most popular leafy vegetables within the continent (Maundu et al., 2009). The Sub Saharan Africa (SSA) region is a natural habitat to more than 45,000 species of LV of which, about 1,000 can be eaten as green leafy or fruit vegetables that happen to be the mainstay of traditional diets (Mac-Calla, 1994). LV subsequently plays a significant role in the food security of the underprivileged in both urban and rural settings (Schippers, 2000; Onyango, 2002a). 
In Nigeria, about 200 indigenous plant species are used as leafy vegetables (Aju \& Popoola, 2010); of these 200, only a few have been fully domesticated, more are semi domesticated and majorities are collected from the wild. A study by Akintoye et.al (2011) reported that the most consumed traditional leafy vegetables in Nigeria include; the Efo yanrin (wild lettuce), Vernonia (Bitter leaf), Amaranthus (African Spinach), Celosia argentea (Lagos Spinach), Talinum Triangulare (Water Leaves), Solanum macrocarpon (Eggplant leaves), Ocimum gratisssimum (scent leaf), Gnelum africanum (Afang), Telfairia occidentalls (Fluted pumpkin leaf) and Cucurbita species (pumpkin leaves). The groceries market were gradually replaced the role of traditional retail market formats, since it provides vary merchandise choices and very organized shop (Chamhuri and Batt, 2013) hence Marketing and consumption of LVs has also been extended to the main urban centres, thanks to people's increasing awareness of their nutritive value (Kimiywe, 2006).

The potential to achieve food safety exists because recent studies have confirmed that with increasing per capita incomes in countries, and as cities become more urbanized, dietary needs change and people become more health conscious, so they tend to demand safer foods (Annan-Prah Mensah, Akorli, Asare, \& Kumi-Die, 2012; Mergenthaler, Weinberger, \& Qaim, 2009). Smallholder vegetable farmers are normally not well-organized; hence their prices vary depending on the purchasing point/outlets. However, the literature gap that exists in this area is the lack of empirical evidence to deepen understanding of how consumers' socio-economic characteristics affect their preference for purchasing point/outlets for safer vegetables. Understanding what motivates consumers to choose one retail outlet from another retail outlet is vital for the successful development of strategies to compete in today's complex markets. The research questions address consumers' main market outlets choice and the determinants that influence the market outlets for fresh leafy vegetables among rural and urban households in Federal Capital Territory, Nigeria, Nigeria.

The study intends to provide answers to the following research questions:

- What are the socio- economic characteristics of consumers choice of market outlets for fresh leafy vegetables used by the rural and urban households in the study area?

- What are the main market outlets for fresh leafy vegetables used by the rural and urban households in the study area?

- What are the determinants that influence choice of market outlets of fresh leafy vegetables among rural and urban households in the study area?

The broad objective of this study is to examine consumers' choice of market outlets for fresh leafy vegetables among rural and urban households in Federal Capital Territory, Nigeria. The specific objectives were to:

- Identify the socio- economic characteristics of consumers choice of market outlets for fresh leafy vegetables used by the rural and urban households in the study area?

- Identify the main market outlets for fresh leafy vegetables used by the rural and urban households in the study area.

- Examine the determinants that influence choice of market outlets of fresh leafy vegetables among rural and urban households in the study area

The study was guided by the following hypotheses:

- $\mathrm{Ho}_{1}$ : there is no significant relationship between the choice of market outlets for fresh leafy vegetables and socio-economic characteristics by rural households in the study area;

- $\mathrm{Ho}_{2}$ : there is no significant relationship between the choice of market outlets for fresh leafy vegetables and socio-economic characteristics by urban households in the study area.

\section{EMPIRICAL REVIEW}

Eric, Oscar, George and Wolfgang (2016) in their study evaluated socio-economic, institutional and product characteristics that influence the choice for African indigenous vegetable (AIV) retail outlets among rural and urban households in Kenya. Multistage 
sampling technique was used to select a sample of 450 respondents from four counties in Kenya. Data was collected using a pre-tested semi-structured questionnaire and a multinomial Probit model was used in the analysis. Their findings revealed that local open air markets and green groceries were the most preferred retail outlets in rural and urban households, respectively. Additionally, gender, age and education level of the key decisionmaker, household size, varietal diversity, vegetable bunch size, market distance and perceptions regarding AIV retail prices significantly influenced the choice for AIV retail outlets. Interventions that would standardize the quantity of vegetables sold per bunch in both supermarkets and green groceries and a further development of more green grocery retail outlets can increase their preference in urban households. Moreover, strategies that would expand farm gate varietal diversity and reinforce hygiene standards in local open air outlets can enhance their preference in rural households.

In a related study by Adinan, Samuel, and Hamdiyah (2018) to assess consumers' preferred purchasing outlet of safer vegetables in Ouagadougou, Burkina Faso using Multinomial Logit, a semi-structured questionnaire was administered on 350 consumers of vegetables (cabbage, lettuce and tomatoes) selected through a multistage random sampling procedure from 10 districts of the capital city, Ouagadougou. Descriptive statistics was used in describing consumers' socio-economic characteristics. They used Multinomial logit to estimate how consumers' socio-economic characteristics affect their preference for purchasing point/outlets for safer vegetables. The Garrett's ranking technique was then used to rank the constraints to accessing safe vegetables. The result revealed that $52.57 \%$ of the consumers preferred to buy safer vegetables from the roadside market, $31.43 \%$ preferred to buy from the supermarket, while the remaining $16.00 \%$ preferred to buy from the farm gate. From the estimation results, the supermarket was a preferred choice for the following categories of consumers: the married; the formally educated; the salaried workers; the relatively rich; and those who purchased vegetables much more frequently. With respect to the constraints to accessing safe vegetables, inadequate supply of safe vegetables was ranked first while cultural barriers was the least ranked. Based on the findings, the study recommends that stakeholders should work at scaling up the production of safer vegetables and the marketing of same via the supermarkets. This is against the backdrop of the existence of a potentially huge market among the affluent society of Ouagadougou.

Kyureghian and Nayga (2013) studied the effect of access to supermarkets and grocery stores, convenience stores, specialty food stores, full-service restaurants and limited-service eating places on consumers' purchase of fresh produce, and their findings suggested that there was a significant interaction effect of income and densities of supermarkets and other purchasing outlets in urban areas on consumers' purchase of fruits and vegetables.

\section{MATERIALS AND METHODS OF RESEARCH}

Federal Capital Territory, Nigeria is situated at the center of the country. FCT is located between latitudes $8^{\circ} 25^{\prime}$ and $9^{\circ} 25^{\prime}$ north of the equator and longitudes $6^{\circ} 45^{\prime}$ and $7^{\circ} 45^{\prime}$ east of Greenwich. The territory covers an area of 760,700 hectares. Abuja is bordered on all sides by four (4) states namely; Niger, Nassarawa, Kogi and Kaduna is currently made up of six (6) Area Councils; Gwagwalada, Abuja municipal, Abaji, Kuje, Kwali and Bwari. FCT is situated within the savannah region, the vegetation is dominated by herbaceous plants which are occasionally interspersed with shrubs with moderate climatic conditions which has the potential for supporting crops and vegetables production such as yams, maize, millet and groundnuts and vegetables. FCT has two major seasons; wet and dry seasons. It has annual average temperature ranging from 22 degrees to 37 degrees while annual average rainfall varies from 1.175 - 1.472mm (NBS, 2010).. According to the United Nations (2017), Abuja grew by $139.7 \%$ between 2000 and 2010 , making it the fastest growing city in the world. As of 2015 , the city is experiencing an annual growth of at least $35 \%$, retaining its position as the fastest-growing city on the African continent and one of the fastest-growing in the 
world. As at 2016, the metropolitan area of Abuja is estimated at six million persons, placing it behind only Lagos, as the most populous metro area in Nigeria (United Nations, 2017).

The study used stratified, purposive and convenient sampling techniques to select the respondents (fresh leafy vegetable consumer households). The study area was stratified into the rural and urban areas. Four Area Councils out of Six (6) Area Councils were selected (for convenience and coverage), two (2) for urban area and two (2) for rural area. For the urban area, Abuja Municipal Area Council (AMAC) and Gwagwalada Area Council were the two (2) area councils selected, based on their features: (AMAC and Gwagwalada area councils are metropolitan in nature, has higher population, developed structures as well as other social amenities and where the commodity (fresh leafy vegetables are mostly consumed. The rural area selected for the two (2) area councils are Kwali and Abaji Area Councils selected are based on their features: (Kwali and Abaji area Councils settlement are surrounded by Villages, has lesser population, area with less developed social amenities) and where the commodity (fresh leafy vegetables are produced and consumed. From each area council, half of the number of wards were selected, which represented $50 \%$ of the wards within the Area Council (for fair representation). For urban area, 5 and 6 wards were selected from Gwagawlada and AMAC; and from rural area, 5 wards each were selected purposively from Kwali and Abaji Area Councils considering the features of the rural settlement. Then, thirtythree (33) and 35 households were conveniently selected from each ward selected in the urban and the rural areas respectively, making a total of 363 households for urban and 350 households for the rural area. After the administration of the questionnaires, 294 and 314 responses were used for the analysis for urban and rural households, respectively. This outcome represents $80.9 \%$ and $89.7 \%$ for urban and rural households, respectively, which was found as useful responses for the analysis. Also, convenience sampling was used at a point because there is no reliable sampling framework that was existing for the respective places of the sampling unit.

Data were collected mainly from primary sources for the study. Data were collected from the respondents (heads of households on behalf of the selected households) with wellstructured questionnaire in the study area. Respondents were interviewed on their choice of market outlets for fresh leafy vegetables. Respondents were interviewed to obtain information on their socio-economic characteristics and other factors (age, gender, education level, occupation, household size, household income, market distance, and expenditure of fresh leafy vegetables consumption and on market outlets choice for purchasing fresh leafy vegetables.

Data collected was analyzed with Descriptive and inferential Statistics and multinomial logit model, It is a choice between three or more alternative response (Kartels, Boztug and Muller, 1999). This was used to determine the determinants that influenced the choice of market outlets of fresh leafy vegetables among rural and urban households in FCT, Nigeria.

The multinomial logit model is stated as shown below:

$$
\begin{aligned}
& \operatorname{Pr}(Z=1)=\frac{\beta^{(1)}, \beta^{(2)}, \beta^{(3)}, \beta^{(4)}, \beta^{(5)}}{e^{x \beta(1)}+e^{x \beta(2)}+e^{x \beta(3)}+e^{x \beta(4)}+e^{x \beta(5)}} \\
& \operatorname{Pr}(Z=2)=\frac{e^{x \beta(2)}}{e^{x \beta(1)}+e^{x \beta(2)}+e^{x \beta(3)}+e^{x \beta(4)}+e^{x \beta(5)}} \\
& \operatorname{Pr}(Z=3)=\frac{e^{x \beta(3)}}{e^{x \beta(1)}+e^{x \beta(2)}+e^{x \beta(3)}+e^{x \beta(4)}+e^{x \beta(5)}} \\
& \operatorname{Pr}(Z=4)=\frac{e^{x \beta(4)}}{e^{x \beta(1)}+e^{x \beta(2)}+e^{x \beta(3)}+e^{x \beta(4)}+e^{x \beta(5)}} \\
& \operatorname{Pr}(Z=5)=\frac{e^{x \beta(4)}}{e^{x \beta(1)}+e^{x \beta(2)}+e^{x \beta(3)}+e^{x \beta(4)}+e^{x \beta(5)}}
\end{aligned}
$$

The model, however, is unidentified in the sense that there is more than one solution:

$$
\beta^{(1)}, \beta^{(2)}, \beta^{(3)}, \beta^{(4)}, \beta^{(4)}, \beta^{(5)}
$$


That leads to the same probabilities for $Z=1, Z=2, Z=3, Z=4, Z=5$. To identify the model, one of the $\beta^{(1)}, \beta^{(2)}, \beta^{(3)}, \beta^{(4)}, \beta^{(5)}$ is arbitrarily set to 0 . That is, if we arbitrarily set $\beta^{(2)}=0$, the remaining coefficients $\beta^{(1)}, \beta^{(3)}, \beta^{(4)}$ was measured the consumers choice relative to $Z=2$. Therefore, setting $\beta^{(2)}=0$, the above equation become:

$$
\begin{aligned}
& \operatorname{Pr}(Z=1)=\frac{e^{x \beta(1)}}{e^{x \beta(1)}+1+e^{x \beta(3)}+e^{x \beta(4)}+e^{x \beta(5)}} \\
& \operatorname{Pr}(Z=2)=\frac{1}{e^{x \beta(1)}+1+e^{x \beta(3)}+e^{x \beta(4)}+e^{x \beta(5)}} \\
& \operatorname{Pr}(Z=3)=\frac{e^{x \beta(3)}}{e^{x \beta(1)}+1+e^{x \beta(3)}+e^{x \beta(4)}+e^{x \beta(5)}} \\
& \operatorname{Pr}(Z=4)=\frac{e^{x \beta(4)}}{e^{x \beta(1)}+1+e^{x \beta(3)}+e^{x \beta(4)}+e^{x \beta(5)}} \\
& \operatorname{Pr}(Z=5)=\frac{e^{x \beta(5)}}{e^{x \beta(1)}+1+e^{x \beta(3)}+e^{x \beta(4)}+e^{x \beta(5)}}
\end{aligned}
$$

The relative probability of $Z=1$ to the base category is given as:

$$
\frac{\operatorname{Pr}(Z=1)}{\operatorname{Pr}(Z=3)}=e^{x \beta(1)}
$$

This relative likelihood assumed that $\mathrm{X}$ and $\beta_{k}^{(1)}$ are vectors equal to:

$$
X_{1}, X_{2}, X_{3} \ldots X_{k} \text { and } \beta_{1}^{(1)}, \beta_{2}^{(1)} \ldots . \beta_{k}^{(1)}
$$

Respectively, the ratio of relative likelihood for one unit change in $X_{i}$ relative to the base category is then:

\begin{tabular}{|c|c|c|}
\hline$\underline{\text { Variables }}$ & Description and Measurement & ation \\
\hline Age & Age of Consumer in (Years) & $+/-$ \\
\hline Gender (Sex) & Male or Female Consumer Dummy (1, Male, 0 otherwise) & $+/-$ \\
\hline Educational Level & Number of Years Spent in Schooling (Years) & + \\
\hline Household Size & Number of Members per Household (Number) & $+/-$ \\
\hline Personal income & Income of Consumer per annum in (Naira) & $+/-$ \\
\hline Years of consumption & Years of Vegetable Consumption in (Years) & + \\
\hline Market distance (Proximity) & Distance to Preferred Market Outlets (Km) & $+/-$ \\
\hline Occupation & Occupation of the Consumer ( 1 , if farming, 0 Otherwise) & ? \\
\hline
\end{tabular}

$$
\frac{e^{\beta(1)} x^{1+\cdots+\beta_{i}}{ }^{(1)\left(x_{i+1)+\cdots+\beta_{k}}(1) x k\right.}}{e^{\beta(1)}{ }^{1+\cdots+\beta_{i}}{ }^{(1)\left(x_{i+1)+\cdots+\beta_{k}}(1) x k\right.}}=e^{x \beta(1)}
$$

Therefore, the exponential value of a coefficient was the relative likelihood ratio for unit change in the corresponding variable (Stata Corp, 1999, cited in Enete, 2003).

The dependent variables are retail outlets, which includes: Supermarkets; Local Market; Farm gate; Home; Road Side. $\operatorname{Pr}(Z=1,2,3,4,5)$ was the multinomial choices of the fresh leafy vegetables market outlet in the rural and urban areas. 


\section{RESULTS AND DISCUSSION}

Socio-Economic characteristics of the respondents. The socio-economic characteristics of the respondents (Consumer households) investigated the relationship between the socioeconomic variables outlined in the conceptual frame, the model and retail outlet choice, a questionnaire was developed and administered to the prospective respondents in the study area and the result of the analysis of the returned questionnaire are presented below.

Age of the respondents. A portion of the respondents, about $40 \%(39.5 \%)$ and $27.9 \%$ of rural and urban households, respectively fall within 31-40 years' age bracket. Table 1 shows that Majority of the respondents $99.4 \%$ and $98 \%$ of the respondents (fresh leafy vegetable consumers) fell within active age brackets of not more than 60 years in the rural and urban households in the study area as shown in Table 1 with the average age of 36.4 and 34.6 years of rural and urban households, respectively in the Federal Capital Territory, Nigeria. The result of this study for rural household of fresh leafy vegetable consumers agrees with the findings of Slamet and Nakayasu (2016) that discovered the average age of consumers' choice for vegetable market channels in Indonesia to be 35 years. These findings agree with the study of Otitoju (2008) which found out that the respondents in Benue State, Nigeria had average age of about 35 years.

Marital status of the respondents. The result showed that majority of the sampled respondents, $63.7 \%$ and $61.2 \%$ were married in the rural and the urban households, respectively (Table 1 ). Again, $33.8 \%$ and $36.1 \%$ of the respondents were single while $2.5 \%$ and $1.4 \%$ of them were widow in the rural and the urban households, respectively as shown in Table 2.

Level of Education of the respondents. The results showed that $1.9 \%$ and $3.4 \%$ of the respondents of the rural and the urban households, respectively never attended school that is, they had no formal education, about $98.1 \%$ and $96.6 \%$ of the respondents of the rural and the urban households, respectively, had formal education. Out of the $98.1 \%$ of the respondents that had formal education, about $7.6 \%$ of them attended only primary school, $24.2 \%$ attended secondary school and $66.2 \%$ attended higher institution at various levels in the rural household category while out of the $96.6 \%$ of the respondents in the urban household category that had formal education, $2 \%$ of them attended only primary school, $20.4 \%$ attended secondary school and $74.1 \%$ attended higher institution at various levels (Table 1). The average years of schooling of the respondents as estimated by this study was about 14 years (13.7 years for rural households' consumers, 14.3 years for the urban households as seen in Table 2. This implies that majority of them attended only secondary schools or its equivalents. This agrees with the finding of Nwaru and Onuoha (2010) that found out that a greater parentage of smallholder food crop farmers (both credit using farmers and non-credit farmers) in Imo state, Nigeria, only attempted secondary school or its equivalent and also agrees with the findings of Eric, Oscar, George and Wolfgang (2016) that found out that a greater percentage of respondents (Consumers) of African indigenous vegetables in Kenya only attempted secondary school or its equivalent. This suggests that majority of the consumers of fresh leafy vegetables in the study area were at least literate (they could read and write).

Household size of the respondents. The findings of this study showed that $40.8 \%$ and $44.9 \%$ of the respondents fell within the household size of 4-6 in the rural and the urban households, respectively, while $24.7 \%$ and $27.2 \%$ of them fell within $7-9$ household size as shown in Table 1. The average household size was 6 (6.3) and 8 (7.5) for those in the rural and the urban households, respectively. Household size for respondents in the rural households was more than their urban household counterpart. This result of the rural household consumers agrees with the finding of Muthini (2014) that found that the mean household size is 6.2 of mango farmers' choice of marketing channels in Makueni Kenya. Also, Otitoju and Arene (2010) found that majority of the respondents had the average household size of about 7 people. 
Table 1 - Frequency Distribution of the Respondent by their Socio-economic Characteristics in the study area

\begin{tabular}{|c|c|c|c|c|}
\hline & \multicolumn{2}{|c|}{ Rural Households } & \multicolumn{2}{|c|}{ Urban Households } \\
\hline Age (years) & Frequency & Percentage (\%) & Frequency & Percentage (\%) \\
\hline$\leq 20$ & 20 & 6.4 & 12 & 4.1 \\
\hline $21-30$ & 96 & 30.6 & 104 & 35.4 \\
\hline $31-40$ & 124 & 39.5 & 82 & 27.9 \\
\hline $41-50$ & 60 & 19.1 & 70 & 23.8 \\
\hline $51-60$ & 12 & 3.8 & 20 & 6.8 \\
\hline$>60$ & 2 & 0.6 & 6 & 2.0 \\
\hline Total & 314 & 100.0 & 294 & 100.0 \\
\hline \multicolumn{5}{|l|}{ Marital Status } \\
\hline Single & 106 & 33.8 & 106 & 36.1 \\
\hline Widowed & 8 & 2.5 & 4 & 1.4 \\
\hline Divorced & 0 & 0.0 & 4 & 1.4 \\
\hline Total & 314 & 100.0 & 294 & 100.0 \\
\hline \multicolumn{5}{|l|}{ Level of education } \\
\hline No Formal Education & 6 & 1.9 & 10 & 3.4 \\
\hline Attended primary school & 24 & 7.6 & 6 & 2.0 \\
\hline Attended secondary school & 76 & 24.2 & 60 & 20.4 \\
\hline Attended Tertiary & 208 & 66.2 & 218 & 74.1 \\
\hline Total & 314 & 100.0 & 294 & 100.0 \\
\hline Household Size (Number) & & & & \\
\hline $4-6$ & 128 & 40.8 & 132 & 44.9 \\
\hline $7-9$ & 78 & 24.8 & 80 & 27.2 \\
\hline $10-12$ & 56 & 17.8 & 26 & 8.8 \\
\hline $13-15$ & 10 & 3.2 & 6 & 2.0 \\
\hline Above 15 & 16 & 5.1 & 6 & 2.0 \\
\hline Total & 322 & 100.0 & 294 & 100.0 \\
\hline Primary Occupation of Cons & & & & \\
\hline Farming & 96 & 17.8 & 36 & 12.2 \\
\hline Civil Service & 126 & 40.1 & 70 & 23.8 \\
\hline Teaching & 42 & 13.4 & 46 & 15.6 \\
\hline Trading & 38 & 12.1 & 66 & 22.4 \\
\hline Others & 52 & 16.5 & 76 & 25.9 \\
\hline Total & 314 & 100.0 & 294 & 100.0 \\
\hline Income (Naira) & & & & \\
\hline No Income & 4 & 1.3 & 2 & 0.7 \\
\hline $5,001.00-50,000.00$ & 242 & 77.1 & 172 & 58.5 \\
\hline $50,001.00-100,000.00$ & 48 & 15.3 & 78 & 26.5 \\
\hline $100,001.00-150,000.00$ & 10 & 3.2 & 22 & 7.5 \\
\hline $150,001.00-200,000.00$ & 6 & 1.9 & 8 & 2.7 \\
\hline $200,001.00-250,000.00$ & 2 & 0.6 & 2 & 0.7 \\
\hline $250,001.00-300,000.00$ & 2 & 0.6 & 2 & 0.7 \\
\hline $450,001.00-500,000.00$ & 0 & 0.0 & 2 & 0.7 \\
\hline Total & 314 & 100.0 & 294 & 100.0 \\
\hline Food Consumption Expendi & a)/Month & & & \\
\hline$<5000: 00$ & 14 & 4.5 & 2 & 0.7 \\
\hline $5,000.00-10,000.00$ & 76 & 24.2 & 6 & 2.1 \\
\hline $10,001.00-15,000.00$ & 44 & 14.0 & 36 & 12.3 \\
\hline $15,001.00-20,000.00$ & 60 & 19.1 & 42 & 13.3 \\
\hline $20,001.00-25,000.00$ & 32 & 10.2 & 32 & 10.9 \\
\hline $25,001.00-30,000.00$ & 16 & 5.1 & 28 & 9.6 \\
\hline $30,001.00-35,000.00$ & 10 & 3.2 & 46 & 15.6 \\
\hline $35,001.00-40,000.00$ & 18 & 5.7 & 14 & 4.8 \\
\hline $40,001.00-45,000.00$ & 6 & 1.9 & 26 & 8.8 \\
\hline $45,001: 00-50.000: 00$ & 10 & 3.2 & 4 & 7.5 \\
\hline$>50.000: 00$ & 28 & 8.9 & 58 & 14.4 \\
\hline Total & 314 & 100.0 & & 100.0 \\
\hline Fresh Leafy Vegetable Cons & (Naira) & & & \\
\hline No Expenditure & 6 & 1.9 & 4 & 1.4 \\
\hline$<100.00$ & 2 & 0.6 & 114 & 38.8 \\
\hline $100.00-500.00$ & 220 & 70.1 & 100 & 34.0 \\
\hline $501.00-1000.00$ & 44 & 14.0 & 14 & 4.8 \\
\hline $1001.00-1500.00$ & 6 & 1.9 & 16 & 5.4 \\
\hline $1501.00-2000.00$ & 18 & 5.7 & 12 & 4.1 \\
\hline $2501.00-3000.00$ & 8 & 2.5 & 12 & 4.1 \\
\hline $3501.00-4000.00$ & 2 & 0.6 & 2 & 0.7 \\
\hline $4501.00-5000.00$ & 8 & 2,5 & 14 & 4.8 \\
\hline $5501.00-6000.00$ & 0 & 0.0 & 2 & 0.7 \\
\hline $6501.00-7000.00$ & 0 & 0.0 & 2 & 0.7 \\
\hline$>7000.00$ & 0 & 0.0 & 2 & 0.7 \\
\hline Total & 314 & 100.0 & 294 & 100.0 \\
\hline Distance to Market Outlets ( & & & & \\
\hline$<1$ & 14 & 4.5 & 114 & 38.8 \\
\hline $1-2$ & 202 & 64.3 & 124 & 42.2 \\
\hline $3-4$ & 50 & 15.9 & 16 & 5.2 \\
\hline $5-6$ & 34 & 10.8 & 14 & 4.8 \\
\hline $7-8$ & 14 & 4.5 & 8 & 2.8 \\
\hline $9-10$ & - & - & 12 & 4.1 \\
\hline $11-12$ & - & - & 2 & 0.7 \\
\hline $13-14$ & - & - & 2 & 0.7 \\
\hline $15-16$ & - & - & 2 & 0.7 \\
\hline Total & 314 & 100.0 & 294 & 100.0 \\
\hline
\end{tabular}

Source: Computed from Field data, 2019. 
This also agrees with the finding of Abdulai and Huffman (2000) that the rice farmers in Northern Ghana had the average household size of 8, but disagrees with the result of Nchare (2007) that found that the average family size of arabica coffee producers in Cameroun was 11.

Primary Occupation of the respondents. It is showed that $40.1 \%$ and $23.8 \%$ of the sampled rural household and the urban households' primary occupation, respectively was civil service. About $18 \%$ and $12.2 \%$ of the sampled rural household and the urban households' primary occupation, respectively was farming. More so, $13.4 \%$ and $15.6 \%$ of the sampled rural household and the urban households' primary occupation, respectively was teaching. Also, $12.1 \%$ and $22.4 \%$ of the sampled rural households and the urban households' primary occupation, respectively were trading in the study area.

Average Income of the respondents. Majority of the sampled respondents, $77.1 \%$ and $58.5 \%$ in the rural and the urban household categories average monthly income fell within $\$ 5,001.00$ and $\$ 50,000.00$, respectively as shown in Table 1 . The average income of the sampled rural households and the urban household consumers of the fresh leafy vegetables was $\$ 44,027.00$, and $\$ 68,592.00$ respectively in the study area as shown in Table 2. This implies that urban households' of fresh leafy vegetable consumers earned more than their rural household counterpart.

Food Consumption Expenditure per Week. Table 2 showed that $\$ 32,581.63$ and \$24,763.05 was the respective weekly food consumption expenditure for urban and rural households, respectively. Table 1 showed that $24.2 \%$ of the fresh leafy vegetables consumers of rural household fell within $\$ 5,000.00$ and $\$ 10,000.00$ food consumption per week while $29.1 \%$ of them fell within $\$ 10,000.00$ and $\$ 15,000.00$. Also, $15.6 \%$ of the sampled fresh leafy vegetables urban household consumers had weekly food consumption expenditure of $\$ 30,001.00$ and $\$ 35,000.00$ while $13.3 \%$ of them had weekly food

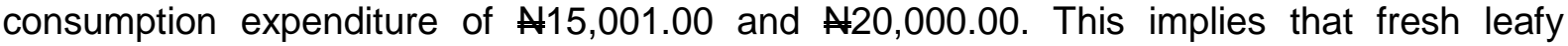
vegetables in the urban households spent more on food consumption per week than their rural household counterpart in the study area. This may be as a result of cost of foodstuff in the urban area.

Fresh Leafy Vegetable Consumption per week. Majority of the sampled respondents (70.1\%) in the rural households expended $\$ 100.00$ to $\$ 500.00$ on fresh leafy vegetables weekly consumption while $38.8 \%$ of the sampled fresh leafy vegetables expended less than N100.00 per week in the study area as shown in Table 1. The average expenditure on fresh leafy vegetables per week was $\$ 1,269.7$ and $\$ 698.03$ for urban and the rural households, respectively (Table 2 ). This implies that fresh leafy vegetables consumers in the urban households spent more on consumption of fresh leafy vegetables per week than their rural household counterpart in the study area. This may be as a result of cost margin attributed to the vegetable market in the urban area

Distance to the market outlets. Table 2 shows that 2.1 and $1.9 \mathrm{~km}$ was the nearest distance of fresh leafy vegetables in the rural and the urban households, respectively. Majority of the respondents $64.3 \%$ and $43 \%$ of the sampled rural and urban households, respectively had a distance between 1 to $2 \mathrm{~km}$ to the market outlets of fresh leafy vegetables from their respective residence as shown in Table 1 . This implies that market outlets are closer to urban household consumers of fresh leafy vegetables in the study area.

Market outlets for fresh leafy vegetable among rural and urban households in the study area. Majority of the respondents $65 \%$ and $76.5 \%$ of the sampled respondents' choice of market outlets for fresh leafy vegetables was local/open-air market by the rural and the urban households, respectively as indicated in Table 2 . These findings agree with the study of Okello, Lagerkvist, Hess, Ngigi \& Karanja (2012) that open-air retail outlet is the major retail outlet for fresh vegetable by urban consumers in Kale, Nairobi, Kenya. Also, 10.6\% and 9.9\% of the sampled rural households choose road side and hawking, respectively as the market outlets for fresh leafy vegetables in the study area. About $8 \%(7.6 \%)$ and $7 \%$ of the sampled rural households choose farm gate and home/kiosks respectively as their market outlets for fresh leafy vegetables in the study area. In the urban household category, $8.8 \%$ and $7.8 \%$ of the sampled respondents choose farm gate and super market respectively as their market 
outlets for fresh leafy vegetables in the study area as shown in Table 2 . More so, about $4 \%$ $(3.7 \%$ and $3.4 \%)$ choose road side and home/ kiosks as market outlets for fresh leafy vegetables in the study area as shown in Table 2.

Table 2 - Frequency Distribution of Respondents by their market outlets for fresh leafy vegetable in the study area

\begin{tabular}{lllll}
\hline & Rural Households & & Urban Households & Percentage \\
\hline Market Outlets & Frequency & Percentage & Frequency & 7.8 \\
\hline Super Market & - & - & 22 & 76.5 \\
Local / Open-air market & 204 & 65.0 & 225 & 8.8 \\
Farm Gate & 24 & 7.6 & 26 & 3.4 \\
Home/ Kiosks & 22 & 7.0 & 10 & 3.7 \\
Road side & 33 & 10.5 & 11 & - \\
Hawking & 31 & 9.9 & - & 100.0 \\
Total & 314 & 100.0 & 294 & \\
\hline
\end{tabular}

Source: Computed from Field data, 2019.

Determinants of choice of market outlets for fresh leafy vegetable among rural and urban households in the study area. This study employed multinomial logit to identify determinants of choice of market outlets for fresh leafy vegetables among rural and urban households in the Federal Capital Territory, Nigeria.

Determinants of Choice of Market Outlets for Fresh Leafy Vegetable among Rural Households in the Study Area. Table 3a presents the results of the Multinomial logit regression model estimated to test the factors that condition consumer choice of market outlet in the rural households for fresh leafy vegetables in the study area. The local/open-air market is used as the base outcome market outlet in the estimation. Table $3 \mathrm{~b}$ presents the marginal effects of the explanatory variables, to avoid the magnitude of the coefficients not to mislead in the interpretation of the contribution of the variables, then the marginal effects were estimated and used for the discussion. The likelihood ratio statistics as indicated by chisquare $\left(x^{2}\right)$ statistics was 152.85 , which was highly significant $(P<0.0000)$ for rural households, suggesting the model has a strong explanatory power.

Age of the respondents. Age of consumers is significantly and negatively related to the probability of choosing farm gate, home/kiosk, and road side as market outlets but the age of the respondents has a higher likelihood to purchase through hawking as a market outlet for fresh leafy vegetables among rural households at $1 \%$ level of probability for farm gate and home/kiosk but at $5 \%$ level of probability for road side and hawking (Table 3a). This showed that young consumers have a higher probability to choose farm gate, home/kiosk and road side as market outlets for fresh leafy vegetables among rural households than the older consumers because they have a wider reasoning faculty and more venturesome. But older consumers preferred to buy fresh leafy vegetables through hawking as a market outlet probably because of the distance associated with the other market outlets. This agrees with apriori expectations. This implies a unit increase in the age of consumers would decrease choice of farm gate, home/kiosks and road side market outlets but would increase the likelihood of choosing hawking market outlet for fresh leafy vegetables among rural households in the study area by $0.373 \%, 0.17 \%, 0.35 \%$, and $4.45 \%$, respectively (Table $3 b$ ).

Gender (Sex) of the respondents. Male household heads have a higher likelihood of choosing road side and hawking market outlets than their female counterparts among the rural households at $1 \%$ and $10 \%$ level of probability, respectively as indicated in (Table 3a). The marginal effects in Table $3 \mathrm{~b}$ indicate that an additional unit of a male-headed household would lead to $7.465 \%$ and $5.0734 \%$ increase in the probability of choosing road side and hawking as market outlets for fresh leafy vegetables respectively in the study area.

Correspondingly, the following study of Deressa et al. (2010) found that malehousehold heads have a positive relationship with choice of sold livestock and livestock borrowed from relatives as a choice of coping and adaptation strategies with climate extremes in the Nile Basin of Ethiopia. 
Education Level of the respondents. The human capital, using education as proxy, of head of household is assumed to have a significant bearing on the choices made on behalf of the households. Most decisions' studies have attempted to measure human capital through education or farming experience. Education of the head of household has direct and significant $(p<0.05)$ relationship with the probability of choice of hawking as market outlet to buy fresh leafy vegetables in the study area. But, education level measured by the years spent in formal schooling has a statistical significant and an inverse relationship with the likelihood to buy fresh leafy vegetables from home/kiosks market outlet at $1 \%$ level of probability (Table $3 b$ ). This implies that a one-unit increase in education (i.e. years of schooling) would lead to $0.742 \%$ increase in the probability of choosing hawking as a market outlet for fresh leafy vegetables by the rural households in the Federal Capital Territory, Nigeria. But for home/kiosk as a market outlet for fresh leafy vegetables an increase in education of the household head would decrease choosing home/kiosk by $4.031 \%$ as indicated in Table 3b.

Household Size of the respondents. The result in Table $3 a$ showed that there is positive relationship between household size and the probability of choosing home/kiosk, road side and hawking as market outlets for fresh leafy vegetables at $1 \%$ level of significance among the rural households in the study area. This implies that one-unit increase in the household size would increase the likelihood to buy fresh leafy vegetables by $0.456 \%$, $0.7741 \%$ and $0.825 \%$ respectively as indicated by marginal effects in Table $3 \mathrm{~b}$.

Fresh leafy vegetable weekly consumption expenditure. The weekly expenditure on fresh leafy vegetables has a negative and significant relationship with

hawking as a market outlet used by rural households at $5 \%$ level of significance as shown in Table 3a. The meaning is that the less a household spend on fresh leafy vegetables weekly the more he chooses hawking as a market outlet to buy the fresh leafy vegetables among the rural households in the study area. As shown by the marginal effect in Table $3 b$, a unit increase in the expenditure on fresh leafy vegetables the less he buys fresh leafy vegetables through hawking by $0.03 \%$. This is in line with a priori expectations.

Distance to the nearest market outlet. The distance of the nearest market outlet of fresh leafy vegetables to rural households has an inverse and significant relationship with home/kiosk, road side and hawking at $1 \%$ level of significance as shown in Table 3a. This implies that proximity counts in purchasing behaviour. The closer the market outlets to the consumers, the more they purchase fresh leafy vegetables through home/kiosks, roadside and hawking in the rural households of the study area. The marginal effect results indicate that a unit increase in the distance to the nearest outlet the less the likelihood to buy fresh leafy vegetables through home/kiosks, roadside and hawking market outlets by $0.135 \%$, $3.523 \%$ and $2.939 \%$ as seen in Table $3 b$.

Table 3a - Parameter Estimates of Determinants of choice of market outlets for fresh leafy vegetable among rural households in the study area

\begin{tabular}{|c|c|c|c|c|c|c|c|c|c|}
\hline \multirow{2}{*}{$\begin{array}{l}\text { Explanatory } \\
\text { Variables }\end{array}$} & \multirow[t]{2}{*}{ Parameters } & \multicolumn{2}{|l|}{ Farm Gate } & \multicolumn{2}{|c|}{ Home / Kiosks } & \multicolumn{2}{|l|}{ Road Side } & \multicolumn{2}{|l|}{ Hawking } \\
\hline & & Coefficient & $\begin{array}{l}z- \\
\text { value }\end{array}$ & Coefficient & $\begin{array}{l}z- \\
\text { value }\end{array}$ & Coefficient & $\begin{array}{l}z \text { - } \\
\text { value }\end{array}$ & Coefficient & $\begin{array}{l}z- \\
\text { value }\end{array}$ \\
\hline Age (Years) $\left(X_{1}\right)$ & $\beta_{1}$ & $\begin{array}{l}-01052 \\
(0.0405)\end{array}$ & -2.60 & $\begin{array}{l}-0.09513 \\
(0.36820)\end{array}$ & $-2.58^{\circ}$ & $\begin{array}{l}-0.07014 \\
(0.02950)\end{array}$ & -2.38 & $\begin{array}{l}0.05764 \\
(0.0272)\end{array}$ & 2.12 \\
\hline Sex (1 Male, 0 otherwise) $\left(X_{2}\right)$ & $\beta_{2}$ & $\begin{array}{l}0.3654 \\
(0.5428)\end{array}$ & 0.67 & $\begin{array}{l}-0.31387 \\
(0.36820)\end{array}$ & -0.46 & $\begin{array}{l}1.4958 \\
(0.46562)\end{array}$ & $3.21^{\mathrm{wx}}$ & $\begin{array}{l}0.84121 \\
(0.48024)\end{array}$ & $1.75^{\circ}$ \\
\hline $\begin{array}{l}\text { Education Level }\left(\mathrm{X}_{3}\right) \text { (Years of } \\
\text { Schooling) }\end{array}$ & $\beta_{3}$ & $\begin{array}{l}-0.11753 \\
(0.07726)\end{array}$ & 1.52 & $\begin{array}{l}-0.20641 \\
(0.0634)^{\prime}\end{array}$ & $-3.27^{* 1 \times}$ & $\begin{array}{l}-0.06096 \\
(0.46562)\end{array}$ & -1.18 & $\begin{array}{l}0.11038 \\
(0.04733)\end{array}$ & $2.33^{\mathrm{xx} x}$ \\
\hline Household Size (Member) $\left(\mathrm{X}_{4}\right)$ & $\beta_{4}$ & $\begin{array}{l}0.00902 \\
(0.68123)\end{array}$ & 0.13 & $\begin{array}{l}0.261984 \\
(0.06926)\end{array}$ & $3.81^{\cdots \prime}$ & $\begin{array}{l}016699 \\
(0.06275)\end{array}$ & $2.66^{\cdots ”}$ & $\begin{array}{l}0.14164 \\
(0.05416)\end{array}$ & $2.62^{\cdots \cdots}$ \\
\hline Personal Income (Naira) $\left(X_{5}\right)$ & $\beta_{5}$ & $\begin{array}{l}-0.00001 \\
(0.00002)\end{array}$ & -0.60 & $\begin{array}{l}-3.44 \mathrm{e}-6 \\
(0.00001)\end{array}$ & -0.33 & $\begin{array}{l}-1.31 \mathrm{e}-06 \\
(9.81 \mathrm{E}-06)\end{array}$ & -0.13 & $\begin{array}{l}2.59 \mathrm{E}-06 \\
(4.52 \mathrm{E}-06)\end{array}$ & 0.57 \\
\hline $\begin{array}{l}\text { Fresh Leafy Vegetable Amount } \\
\text { (Naira) }\left(X_{6}\right)\end{array}$ & $\beta_{6}$ & $\begin{array}{l}-0.000141 \\
(0.00099)\end{array}$ & -1.43 & $\begin{array}{l}-0.0571 \\
(0.00077)\end{array}$ & -0.74 & $\begin{array}{l}-0.00042 \\
(0.00049)\end{array}$ & -0.86 & $\begin{array}{l}-0.00061 \\
(0.00027)\end{array}$ & -2.22 \\
\hline Average Distance $(\mathrm{Km})\left(\mathrm{X}_{7}\right)$ & $\beta_{7}$ & $\begin{array}{l}-0.02034 \\
(0.83013)\end{array}$ & -0.25 & $\begin{array}{l}-0.80110 \\
(0.2956)\end{array}$ & $-2.71^{\prime *}$ & $\begin{array}{l}-0.74111 \\
(0.20190)\end{array}$ & $-3.67^{x \times x}$ & $\begin{array}{l}-0.50949 \\
(0.18826)\end{array}$ & $-2.71^{\mathrm{xm}}$ \\
\hline Constant & $\beta_{0}$ & $\begin{array}{l}0.77022 \\
(1.7466)\end{array}$ & 0.44 & $\begin{array}{l}3.1207 \\
(1.98571)\end{array}$ & 1.57 & $\begin{array}{l}-0.68402 \\
(1.61006)\end{array}$ & -0.42 & $\begin{array}{l}-6.7952 \\
(1.7146)\end{array}$ & -3.96 \\
\hline
\end{tabular}

${ }^{*}, * *, * * *, 10 \%, 5 \%, 1 \%$ levels of significance. Local /Open air Market is the base outcome (comparison category). Source: Computed from field data, 2019. 
Table 3b - Marginal Effect of Parameter Estimates of Determinants of choice of market outlets for fresh leafy vegetable among rural households in the study area

\begin{tabular}{|c|c|c|c|c|c|c|c|c|c|c|c|}
\hline \multirow[t]{2}{*}{$\begin{array}{l}\text { Explanatory } \\
\text { Variables }\end{array}$} & \multirow[t]{2}{*}{ Parameters } & \multicolumn{2}{|c|}{$\begin{array}{l}\text { Local/Open-air } \\
\text { market }\end{array}$} & \multicolumn{2}{|l|}{ Farm Gate } & \multicolumn{2}{|c|}{ Home / Kiosks } & \multicolumn{2}{|l|}{ Road Side } & \multicolumn{2}{|l|}{ Hawking } \\
\hline & & $\mathrm{dy} / \mathrm{dx}$ & $\begin{array}{l}\text { z- } \\
\text { value }\end{array}$ & $d y / d x$ & $\begin{array}{l}z- \\
\text { value }\end{array}$ & $\mathrm{dy} / \mathrm{dx}$ & $\begin{array}{l}z- \\
\text { value }\end{array}$ & $\mathrm{dy} / \mathrm{dx}$ & $\begin{array}{l}z- \\
\text { value }\end{array}$ & $\mathrm{dy} / \mathrm{dx}$ & $\begin{array}{l}z- \\
\text { value }\end{array}$ \\
\hline Age (Years) $\left(X_{1}\right)$ & $\beta_{1}$ & $\begin{array}{l}0.00451 \\
(0.00312)\end{array}$ & 1.45 & $\begin{array}{l}-0.00373 \\
(0.002)\end{array}$ & -1.87 & $\begin{array}{l}-0.0017 \\
(0.00097)\end{array}$ & -1.77 & $\begin{array}{l}-0.0035 \\
(0.0166)\end{array}$ & -2.11 & $\begin{array}{l}0.04445 \\
(0.03102)\end{array}$ & 2.57 \\
\hline Sex (1 Male, 0 otherwise) $\left(X_{2}\right)$ & $\beta_{2}$ & $\begin{array}{l}-0.09891 \\
(0.4783)\end{array}$ & -2.07 & $\begin{array}{l}-0.01819 \\
(0.1955)\end{array}$ & -0.93 & $\begin{array}{l}-0.0082 \\
(0.0130)\end{array}$ & -0.63 & $\begin{array}{l}0.07465 \\
(0.02724)\end{array}$ & 2.74 & $\begin{array}{l}0.050734 \\
(0.03102)\end{array}$ & 1.64 \\
\hline $\begin{array}{l}\text { Education Level }\left(\mathrm{X}_{3}\right) \text { (Years of } \\
\text { Schooling) }\end{array}$ & $\beta_{3}$ & $\begin{array}{l}-0.00403 \\
(0.00501)\end{array}$ & -0.80 & $\begin{array}{l}0.04213 \\
(0.00267)\end{array}$ & 1.58 & $\begin{array}{l}-0.04031 \\
(0.00204)\end{array}$ & $-1.98^{*}$ & $\begin{array}{l}-0.003577 \\
(0.00271)\end{array}$ & -1.32 & $\begin{array}{l}0.00742 \\
(0.00742)\end{array}$ & $2.50^{\mathrm{x*}}$ \\
\hline $\begin{array}{l}\text { Household Size (Member) } \\
\left(\mathrm{X}_{4}\right)\end{array}$ & $\beta_{4}$ & $\begin{array}{l}-0.01999 \\
(0.00584)\end{array}$ & $-3.42^{x+m}$ & $\begin{array}{l}-0.00057 \\
(0.0024)\end{array}$ & -0.23 & $\begin{array}{l}0.00456 \\
(0.00217)\end{array}$ & $2.11^{\pi *}$ & $\begin{array}{l}0.007741 \\
(0.00331)\end{array}$ & $2.34^{\prime \prime}$ & $\begin{array}{l}0.00825 \\
(0.00346)\end{array}$ & $2.39^{* *}$ \\
\hline Personal Income (Naira) $\left(\mathrm{X}_{5}\right)$ & $\beta_{5}$ & $\begin{array}{l}2.83 \mathrm{e}-07 \\
(0.0000)\end{array}$ & 0.35 & $\begin{array}{l}-3.79 \mathrm{e}-07 \\
(0.0000)\end{array}$ & -0.62 & $\begin{array}{l}-5.91 \mathrm{E}- \\
08 \\
(0.0000)\end{array}$ & -0.30 & $\begin{array}{l}-5.21 \mathrm{E}-08 \\
(0.00000)\end{array}$ & -0.10 & $\begin{array}{l}2.07 \mathrm{E}-07 \\
(0.0000)\end{array}$ & 0.70 \\
\hline $\begin{array}{l}\text { Fresh Leafy Vegetable } \\
\text { Amount (Naira) }\left(\mathrm{X}_{6}\right)\end{array}$ & $\beta_{6}$ & $\begin{array}{l}0.00111 \\
(0.00004)\end{array}$ & $2.60^{\mathrm{nx*}}$ & $\begin{array}{l}0.0024 \\
(0.0003)\end{array}$ & $-1.72^{*}$ & $\begin{array}{l}-8.41 \mathrm{e}-06 \\
(0.00001)\end{array}$ & -0.60 & $\begin{array}{l}-0.00001 \\
(0.00003)\end{array}$ & -0.64 & $\begin{array}{l}-0.0003 \\
(0.00002)\end{array}$ & $-1.93^{*}$ \\
\hline Average Distance $(\mathrm{Km})\left(\mathrm{X}_{7}\right)$ & $\beta_{7}$ & $\begin{array}{l}0.07546 \\
(0.01451)\end{array}$ & 5.20 & $\begin{array}{l}0.0026 \\
(0.0316)\end{array}$ & 0.85 & $\begin{array}{l}-0.0135 \\
(0.00596)\end{array}$ & $-2.27^{* *}$ & $\begin{array}{l}-0.035234 \\
(0.00613)\end{array}$ & $\overline{3}^{-} .86^{* * *}$ & $\begin{array}{l}-0.02939 \\
(0.01018)\end{array}$ & $\overline{2}^{-} .89^{* * *}$ \\
\hline
\end{tabular}

*, **, ***, 10\%, 5\%, 1\% levels of significance. Source: Computed from field data, 2019.

Determinants of Choice of Market Outlets for Fresh Leafy Vegetable among Urban Households in the Study Area. Table 4b presents the result of the multinomial logit regression model parameter estimates and the marginal effect respectively to test the factors that condition consumer choice of market outlet in the urban households for fresh leafy vegetables in the study area. The marginal effects from the Multinomial Logit (MNL) model, which measure the expected change in the probability of a particular choice being made with respect to a unit change in an independent variable, are reported and discussed. The marginal effects were used for interpretation since the coefficients had no direct interpretation. They were just values that maximized the likelihood function. The significant values showed whether a change in the independent variable significantly influences the logit at a given market outlets adoption strategy.

The MNL model fitted the data reasonably well. The Chi-square value of -243.085 showed that the likelihood ratio statistics were highly significant $(P<0.000)$. The Wald test that all regression coefficients were jointly equal to zero was rejected [LR X2 (8) = 34.97; Prob $\left.>x^{2}=0.000\right]$, suggesting that the MNL model had strong explanatory power.

Age of the respondents. Age of the household head had a positive and significant influence on choosing farm gate, but negatively related to home/kiosk. This implied that, relative to the base category of local/open air market, an increase in the age of household heads among the urban households by 1 year increase the probability of purchasing from the farm gate by $0.334 \%$. Also a unit increase in the age of the consumers would decrease the likelihood of choosing home/kiosk as a market outlet for fresh leafy vegetables among urban households in the study area by $0.114 \%$. This could be attributed to the possibility that older household heads had more children and dependents and the cost of purchasing fresh leafy vegetables may be less compare to other market outlets. This result conforms to the a priori expectation.

Gender of the respondents. Gender has a negative and significant relationship with the probability to choose road side for the purchase of fresh leafy vegetables in the urban area of the study area (Table 4a). This means that female household heads have a higher likelihood of choosing road side market outlets than their male counterparts among the urban households in the study area at $1 \%$ level of probability. The marginal effects in Table $3 \mathrm{~b}$ indicate that an additional unit of a male-headed household would lead to $0.0000291 \%$ decrease in the probability of choosing road side as a market outlet for fresh leafy vegetables among the urban households in the study area.

Education Level of the respondents. Education of the head of household has negative and significant relationship with the probability of choice of super markets and farm gate as market outlets to purchase fresh leafy vegetables at $10 \%$ and $1 \%$ levels of probability, respectively among the urban households in the study area as seen in Table 4a. This findings does not confirm with the apriori expectation.

This implies that a one-unit increase in education (i.e. years of schooling) would lead to $0.326 \%$ and $0.851 \%$ decrease in the probability of choosing super market and farm gate as 
market outlets for fresh leafy vegetables by the urban households in the Federal Capital Territory, Nigeria as indicated by their marginal effects in Table 4b.

Household Size of the respondents. Table $4 a$ showed that there is positive and statistically significant relationship between household size and the probability of choosing super markets as a market outlet for fresh leafy vegetables at $10 \%$ level of significance among the urban households in the study area. This implies that one-unit increase in the household size would increase the likelihood to buy fresh leafy vegetables by $0.906 \%$ as indicated by marginal effects in Table $4 \mathrm{~b}$. This means that households with less number of people purchase fresh leafy vegetables from super markets in the urban area of the Federal Capital Territory.

Personal income. Income has great effect in making decision by household heads. In this study, average income has positive and significant relationship with consumers' choice of supermarket and home/kiosk as market outlets for purchase of fresh leafy vegetables by urban households in the study area. This implies that urban household heads with higher personal income are more willing to choose super markets and home/kiosks than those with lower income who preferred to choose road side to purchase fresh leafy vegetables in the study area.

But there is an inverse relationship between income and road side market outlet for the purchase of fresh leafy vegetables among urban households in the study area (Table 4a). This negative relationship showed that urban household heads with lower income preferred road side as their own market outlets where they purchase fresh leafy vegetables.

It implies that a unit increase in personal income of the urban consumer household heads would increase the probability to choose super markets and home/kiosk as market outlets for fresh leafy vegetables by $0.000044 \%$ in the study area as shown by Table $4 \mathrm{~b}$. However, a unit increase in the personal income of urban households' consumers of fresh leafy vegetables would decrease the choice of road side as a market outlet by $0.00000000438 \%$ as indicated in Table 4b.

Fresh leafy vegetable weekly consumption expenditure. Consumption of fresh leafy vegetable weekly expenditure by urban consumers' households has an inverse and significant relationship with super market and road side as market outlets at $1 \%$ and $5 \%$ levels of probability as shown in Table $4 \mathrm{a}$. The meaning is that the less household heads spend on fresh leafy vegetables weekly the more they choose super market and road side as market outlets to buy the fresh leafy vegetables among the urban households in the study area. As shown by the marginal effect in Table 4b, a unit increase in the expenditure on fresh leafy vegetables among urban households, the less they buy fresh leafy vegetables from super markets and road side by $0.004 \%$ and $0.000000212 \%$ respectively.

Table 4a - Parameter Estimates of Determinants of Choice of Market Outlets for Fresh Leafy Vegetables among Urban Households in the study area

\begin{tabular}{|c|c|c|c|c|c|c|c|c|c|}
\hline \multirow{2}{*}{$\begin{array}{l}\text { Explanatory } \\
\text { Variables }\end{array}$} & \multirow[t]{2}{*}{ Parameters } & \multicolumn{2}{|c|}{ Super Market } & \multicolumn{2}{|l|}{ Farm Gate } & \multirow[t]{2}{*}{ Home / Kiosks } & \multicolumn{2}{|c|}{ Road side } & \multirow[b]{2}{*}{ z-value } \\
\hline & & Coefficient & $\begin{array}{l}z- \\
\text { value }\end{array}$ & Coefficient & $\begin{array}{l}z- \\
\text { value }\end{array}$ & & $\begin{array}{l}z- \\
\text { value }\end{array}$ & Coefficient & \\
\hline Age (Years) $\left(\mathrm{X}_{1}\right)$ & $\beta_{1}$ & $\begin{array}{l}0.00452 \\
(0.02481)\end{array}$ & 0.18 & $\begin{array}{l}-0.05377 \\
(0.02950)\end{array}$ & 2.56 & $\begin{array}{l}-0.01463 \\
(0.02006)\end{array}$ & -7.30 & $\begin{array}{l}-0.02177 \\
(0.03412)\end{array}$ & -0.64 \\
\hline Sex (1 Male, 0 otherwise) $\left(X_{2}\right)$ & $\beta_{2}$ & $\begin{array}{l}-0.41344 \\
(0.56169)\end{array}$ & -0.74 & $\begin{array}{l}-1.4958 \\
(0.46562)\end{array}$ & -1.28 & $\begin{array}{l}0.36001 \\
(0.44473)\end{array}$ & 0.81 & $\begin{array}{l}-1.51328 \\
(0.44373)\end{array}$ & - \\
\hline $\begin{array}{l}\text { Education Level }\left(\mathrm{X}_{3}\right) \text { (Years of } \\
\text { Schooling) }\end{array}$ & $\beta_{3}$ & $\begin{array}{l}-0.0660 \\
(0.03744)\end{array}$ & -1.76 & $\begin{array}{l}-0.06096 \\
(0.46562)\end{array}$ & -2.97 & $\begin{array}{l}-0.11580 \\
(0.10142)\end{array}$ & -1.14 & $\begin{array}{l}-0.08919 \\
(0.0979)^{\prime}\end{array}$ & 0.91 \\
\hline Household Size (Member) $\left(X_{4}\right)$ & $\beta_{4}$ & $\begin{array}{l}0.14775 \\
(0.0758\end{array}$ & $1.95^{*}$ & $\begin{array}{l}016699 \\
(0.06275)\end{array}$ & -0.73 & $\begin{array}{l}-0.03575 \\
(0.12061)\end{array}$ & -0.30 & $\begin{array}{l}0.01009 \\
(0.12042)\end{array}$ & 0.08 \\
\hline Personal Income (Naira) $\left(\mathrm{X}_{5}\right)$ & $\beta_{5}$ & $\begin{array}{l}-7.22 \mathrm{e}-06 \\
(3.75 \mathrm{e}-06)\end{array}$ & $1.92^{*}$ & $\begin{array}{l}-1.31 \mathrm{e}-06 \\
(9.81 \mathrm{E}-06)\end{array}$ & -1.15 & $\begin{array}{l}0.00001 \\
(5.85 \mathrm{E}-06)\end{array}$ & $2.76^{x \times \pi}$ & $\begin{array}{l}-0.00002 \\
(0.000017)\end{array}$ & $-2.61^{x * x}$ \\
\hline $\begin{array}{l}\text { Fresh Leafy Vegetable Amount } \\
\text { (Naira) }\left(\mathrm{X}_{6}\right)\end{array}$ & $\beta_{6}$ & $\begin{array}{l}-0.00069 \\
(0.00019)\end{array}$ & $-3.56^{x \times x}$ & $\begin{array}{l}-0.00042 \\
(0.00049)\end{array}$ & -0.69 & $\begin{array}{l}-0.00009 \\
(0.00014)\end{array}$ & -0.66 & $\begin{array}{l}-0.00145 \\
(0.00071)\end{array}$ & $-2.03^{* x}$ \\
\hline Average Distance $(\mathrm{Km})\left(\mathrm{X}_{7}\right)$ & $\beta_{7}$ & $\begin{array}{l}-0.08427 \\
(0.07347)\end{array}$ & 1.15 & $\begin{array}{l}-0.74111 \\
(0.20190)\end{array}$ & $2.30^{1 \times}$ & $\begin{array}{l}-1.06621 \\
(0.081072)\end{array}$ & -1.32 & $\begin{array}{l}-2.33808 \\
(1.47038)\end{array}$ & -1.59 \\
\hline Constant & $\beta_{0}$ & $\begin{array}{l}-3.1636 \\
(1.44047) \\
\end{array}$ & $-2.20^{\mathrm{xx}}$ & $\begin{array}{l}-0.68402 \\
(1.61006) \\
\end{array}$ & -0.59 & $\begin{array}{l}2.90843 \\
(1.81723) \\
\end{array}$ & 1.60 & $\begin{array}{l}14.7716 \\
(1.55341)\end{array}$ & $9.51^{\mathrm{xx}}$ \\
\hline
\end{tabular}

*, **, ***,10\%,5\%, 1\% levels of significance. Local /Open-air Market is the base outcome (comparison category). Source: Computed from field data, 2019. 
Distance to the nearest market outlet. Distance to the nearest market outlet of fresh leafy vegetables to urban households has an inverse and significant relationship with farm gate at $5 \%$ level of significance as shown in Table 3a. This implies that proximity counts in purchasing behaviour. The farther the market outlets to the consumers the lesser they purchase fresh leafy vegetables at farm gate by the urban households in the study area. The marginal effect results indicate that a unit increase in the distance to the nearest outlet the more the likelihood to buy fresh leafy vegetables through the farm gate by $1.077 \%$ as seen in Table 4b.

Table 4b - Marginal Effect of Parameter Estimates of Determinants of choice of market outlets for fresh leafy vegetable among urban households in the study area

\begin{tabular}{|c|c|c|c|c|c|c|c|c|c|c|c|}
\hline \multirow{2}{*}{$\begin{array}{l}\text { Explanatory } \\
\text { Variables }\end{array}$} & \multirow[t]{2}{*}{ Parameters } & \multicolumn{2}{|c|}{ Super market } & \multicolumn{2}{|c|}{ Local/Open market } & \multicolumn{2}{|l|}{ Farm Gate } & \multicolumn{2}{|c|}{ Home / Kiosks } & \multicolumn{2}{|l|}{ Road Side } \\
\hline & & $\mathrm{dy} / \mathrm{dx}$ & $z$-value & $\mathrm{dy} / \mathrm{dx}$ & $z$-value & $\mathrm{dy} / \mathrm{dx}$ & $z$-value & $\mathrm{dy} / \mathrm{dx}$ & $z$-value & $\mathrm{dy} / \mathrm{dx}$ & $z$-value \\
\hline Age (Years) $\left(\mathrm{X}_{1}\right)$ & $\beta_{1}$ & $\begin{array}{l}0.00012 \\
(0.00147)\end{array}$ & 0.08 & $\begin{array}{l}-0.00232 \\
(0.0024)\end{array}$ & -0.97 & $\begin{array}{l}0.00334 \\
(0.00016)\end{array}$ & $2.09^{\prime \prime}$ & $\begin{array}{l}-0.00114 \\
(0.0045)\end{array}$ & -0.98 & $\begin{array}{l}2.91 \mathrm{E}-08 \\
(0.00000)\end{array}$ & 0.52 \\
\hline $\begin{array}{l}\text { Sex (1 Male, } 0 \text { otherwise) } \\
\left(X_{2}\right)\end{array}$ & $\beta_{2}$ & $\begin{array}{l}0.02704 \\
(0.03136)\end{array}$ & 0.86 & $\begin{array}{l}0.04165 \\
(0.04165)\end{array}$ & 0.26 & $\begin{array}{l}-0.0287 \\
(0.0016)\end{array}$ & -1.43 & $\begin{array}{l}-0.0028 \\
(0.00452)\end{array}$ & 0.63 & $\begin{array}{l}0.000023 \\
(0.00000)\end{array}$ & -0.49 \\
\hline $\begin{array}{l}\text { Education Level }\left(X_{3}\right) \\
\text { (Years of Schooling) }\end{array}$ & $\beta_{3}$ & $\begin{array}{l}-0.00326 \\
(0.0023)\end{array}$ & -1.42 & $\begin{array}{l}0.01255 \\
(0.00362)\end{array}$ & $3.47^{* \prime \prime}$ & $\begin{array}{l}-0.00851 \\
(0.0024)\end{array}$ & $-3.41^{\prime \prime \prime}$ & $\begin{array}{l}-0.00007 \\
(0.00073)\end{array}$ & -1.06 & $\begin{array}{l}1.58 \mathrm{E}-07 \\
(0.00000)\end{array}$ & 0.56 \\
\hline $\begin{array}{l}\text { Household Size } \\
\text { (Member) }\left(X_{4}\right)\end{array}$ & $\beta_{4}$ & $\begin{array}{l}0.00906 \\
(0.00388)\end{array}$ & $2.34^{*}$ & $\begin{array}{l}-0.004227 \\
(0.0064)\end{array}$ & -0.66 & $\begin{array}{l}-0.0045 \\
(0.00517)\end{array}$ & -0.88 & $\begin{array}{l}-0.00031 \\
(0.0008)\end{array}$ & -0.36 & $\begin{array}{l}7.94 \mathrm{E}-09 \\
(0.00000)\end{array}$ & 0.04 \\
\hline $\begin{array}{l}\text { Personal Income (Naira) } \\
\left(\mathrm{X}_{5}\right)\end{array}$ & $\beta_{5}$ & $\begin{array}{l}4.40 \mathrm{e}-07 \\
(0.0000)\end{array}$ & $1.83^{*}$ & $\begin{array}{l}-2.43 \mathrm{e}-07 \\
(0.0000)\end{array}$ & -0.69 & $\begin{array}{l}-3.19 \mathrm{E}-07 \\
(0.0000)\end{array}$ & -1.25 & $\begin{array}{l}1.21 \mathrm{E}-07 \\
(0.00000)\end{array}$ & 1.08 & $\begin{array}{l}-4.38 \mathrm{E}-11 \\
(0.00000)\end{array}$ & 0.00 \\
\hline $\begin{array}{l}\text { Fresh Leafy Vegetable } \\
\text { Amount (Naira) }\left(\mathrm{X}_{6}\right)\end{array}$ & $\beta_{6}$ & $\begin{array}{l}-0.00004 \\
(0.00001)\end{array}$ & $-3.30 "$ & $\begin{array}{l}0.00052 \\
(0.0002)\end{array}$ & $2.25 "$ & $\begin{array}{l}-0.00001 \\
(0.00002)\end{array}$ & -0.58 & $\begin{array}{l}-2.69 \mathrm{E}-07 \\
(0.00000)\end{array}$ & -0.22 & $\begin{array}{l}-2.12 \mathrm{E}-09 \\
(0.00000)\end{array}$ & -0.47 \\
\hline $\begin{array}{l}\text { Average Distance }(\mathrm{Km}) \\
\left(\mathrm{X}_{7}\right)\end{array}$ & $\beta_{7}$ & $\begin{array}{l}0.00480 \\
(0.00419)\end{array}$ & 1.15 & $\begin{array}{l}-0.00735 \\
(0.0064)\end{array}$ & -1.15 & $\begin{array}{l}0.01077 \\
(0.00402)\end{array}$ & $2.68^{* \prime \prime}$ & $\begin{array}{l}-0.00823 \\
(0.00381)\end{array}$ & $-2.16^{*}$ & $\begin{array}{l}-3.58 \mathrm{E}-06 \\
(0.00000)\end{array}$ & -0.69 \\
\hline
\end{tabular}

${ }^{*},{ }^{* *},{ }^{* *}, 10 \%, 5 \%, 1 \%$ levels of significance. Source: Computed from field data, 2019.

\section{CONCLUSION}

The study revealed that the consumers' preferred Local/open air market as their main market outlets for fresh leafy vegetables for both rural and urban households in the study area. It was revealed that choice of market outlets for fresh leafy vegetables were influenced by age, gender, education, household size, weekly expenditure on fresh leafy vegetables and distance to the nearest market outlets among the rural households while age, gender, education, household size, personal income, weekly expenditure on fresh leafy vegetables and distance to the nearest market outlets influenced the choice of market outlets among the urban households in Federal Capital Territory, Nigeria. The findings of the study have some important policy implications for enhancing the choice of market outlets for fresh leafy vegetables among rural and urban households. Consumers should be properly educated by the relevant bodies (government, Health Workers, Media Groups) on the importance of various market outlets for fresh leafy vegetables in the study area. Government should embark on strategies that would focus on formulating, implementing and reinforcing hygienic standards in local open air retail outlets which would adequately enhance consumer's preference for local / open air market outlets. This could be achieved through construction of market shades and drainage systems as well as ensuring marketers' sells clean vegetables, which are well displayed, packaged and handled. Facilities such as plastic crates should be encouraged for carrying, transporting and handling fresh leafy vegetables fresh for longer period of time as compared to the commonly used plastics and gunny bags, which damage vegetable by fermentation due to accumulation of heat in the bags. Further strategies that would expand fresh leafy vegetables varietal diversity at the farm gate outlets would enhance their choice among rural households. Also, policies that would enhance investment in research and production of certified seeds for various fresh leafy vegetables and supplying them to farmers for use by relevant government organization(s) would enhance fresh leafy vegetables varietal diversity. More so, educating farmers, through existing agricultural extension service providers would be key in enhancing fresh leafy vegetables varietal diversity at the farm gate Interventions that would standardize the unit quantity of a vegetable bunch across vegetable seasons would motivate consumers' preference for supermarkets in urban households. In addition, promotional strategies that would encourage more supermarkets to sell fresh leafy vegetables accessibility thereby enhancing supermarket choice among urban households. 


\section{REFERENCES}

1. Abdulai, A. \& Huffman, W. (2000). Structural adjustment and economic efficiency of rice farmers in Northern Ghana. Economic Development and Cultural Change, 48(3), 503520.

2. Adinan, B.S, Samuel, A. D. \& Hamdiyah, A (2018). "Consumers' preferred purchasing outlet of safer vegetables in Ouagadougou, Burkina Faso". Journal of Cogent Food Agriculture, 4: 1489714.

3. Aju P. C. \& Popoola, L. (2010). The Marketing and Potentials of indigenous leafy vegetables in South Eastern Nigeria. In L. Popoola, O. Y. Ogunsanwo \& F. E. Idumah (eds). Proceedings of 34th Annual Conference of Forestry Association of Nigeria. Osogbo, Nigeria pp $114-124$.

4. Annan-Prah, A. Mensah, A. A. Akorli, S. Y. Asare, P. T. \& Kumi-Die, I. D. (2012). Slaughterhouses, Animal Slaughter and Slaughter Hyegiene in Ghana. Journal of Veterinary Advances, 2(4): 189-198.

5. Chamhuri N, \& Batt, P. (2013). Exploring the factors influencing consumers' choice of retail store when purchasing fresh meat in Malaysia. International Journal of food and agribusiness management review. 6(3): 99-122.

6. Deressa, T. T., Ringler, C. \& Hassan, R.M. (2010). Factors affecting the choices of coping strategies for climate extremes: the case of farmers in the Nile Basin of Ethiopia (Final START, ACCFP Report) African Climate Change Fellowship Program (ACCFP).

7. Efa, G. T. \& Tura, K. H. (2018). Determinants of Tomato smallholder farmers market outlet choice in west Shewa Ethopia. Department of Geography and Tourism, Canterbury, Christ church University College, Canterbury Kart, UK.

8. Eric, O. G, Oscar, I. A., George, O. \& Wolfgang, B. (2016). Consumption intensity of leafy African Indigenous Vegetables: Comparison between Rural and Urban dwellers. International Journal of Vegetables Science, 23(4):346 - 361.

9. Kartels, K, Y. Boztug and M. Muller, (1999). Testing the Multinomial Logit Model Retrieved June 14, 2008, from http://www.mkartels.org.

10. Kimiywe J. (2006). Ultilization and medicinal value of indeigenous leafy vegetables consumed in urban and

11. Kyureghian G. Rodolfo M. Nayga, Jr. \& Suparna B. (2013). The effect of food store access and income household purchase of fruits and vegetables: mix effect analysis. Applied economic perspective and policy. Agricultural and Applied Economic Association 35(1): 61-88

12. pesi - urban Narobi. African Journal Food Agric. Nutri Development, 7(4).

13. Maundu, P., Achigan-Dako, E. G. and Morimoto, Y. (2009). Biodiversity of African Vegetables. In: Shackleton,C. M., Pasquini, M W. and Drescher, A. W. (eds) African Indigenous Vegetables in Urban Agriculture. Earthscan, London: 65-104.

14. Mergenthaler, M. Weinbkn n ger, K., \& Qaim, M (2009). The food system transformation in developing countries. A disaggregate demand analysis for fruits and vegetables in Vietnam. Food policy, 34(5): 426-436.

15. Muthini, D.N. (2015). An assessment of mango farmers' choice of marketing channels in Makueni, Kenya. A Master of Science thesis, Department of Agricultural Economics. University of Nairobi, Kenya.

16. Natarajan, B. (2002). Conservation of Biological Diversity and Indigenous Traditional

17. Knowledge as Exemplified By the Cases of Asia and Africa. Indilinga-African

18. Journal of Indigenous Knowledge Systems, 1:

19. Nchare, A. (2007). Analysis of factors affecting technical efficiency of Arabica coffee producers in Cameroun. (AERC Research paper 163). Nairobi, Kenya: African Economic Research Consortium.

20. Nwaru, J.C. \& Onuoha, R.E. (2010). Credit use and technical change in smallholder food crop production in Imo State, Nigeria. New York Science Journal, 3(11), 144-151.

21. Okello, J. J., Lagerkvist, C., Hess, S., Ngigi, M. \& Karanja, N. (2012). Choice of Fresh Vegetable Retail Outlets by Developing-Country Urban Consumers: The Case of Kale 
Consumers in Nairobi, Kenya. European Journal of Development Research, 24: 434449. Doi:10.1057/ejdr.2011.58.

22. Onyango, M. O. A. (2002a). Market Survey on African Indigenous Vegetables in Western Kenya. In: Proceedings of the 2 nd

23. JKUAT/DAAD Workshop on Sustainable Horticultural Production in the Tropics 6th-9th August 2002: 39-46.

24. Otitoju, M. A. (2008). Determinants of technical efficiency in small and medium-scale soybean production in Benue State, Nigeria. Unpublished M.Sc dissertation, Department of Agricultural Economics, University of Nigeria, Nsukka.

25. Otitoju, M. A. \& Arene, C. J. (2010). Constraints and determinants of technical efficiency in medium-scale soybean production in Benue State, Nigeria. African Journal of Agricultural Research, 5(17), 2276-2280. Available online at http://www.academicjournals.org/AJAR.

26. Slamet, A. S. \& Nakayasu, A. (2016). Consumers' Choice for Vegetable Market Channels in Indonesia, KnE Life Sciences, 3: 31 - 36. ICoA Conference Proceedings, 7 - 9 November 2015. DOI: http://dx.doi.org/10.18502/kls.v3i3.386.

27. Schippers, R.R. (2000). African indigenous vegetables: An overview of the cultivated species. Natural Resources Institute/ACP-EU Technical Centre for Agricultural and Rural Cooperation, Chatham.

28. Smith, F. I. \& Eyzaguirre, P. (2007). African leafy vegetables: Their role in the world health organization's global fruit and vegetables initiative. African Journal of Food, Agriculture and Nutrition Development, 7(3): 1- 17.

29. StataCorp. (2003). Stata base reference manual. Volume 4, G-M, release 8. College Station, TX: Stata Corporation.

30. StataCorp (1999). Stata Statistical Software; Release 6.0 Collage Station, TX; Stata Corporation, Texas, U.S.A.

31. World Health Organization (WHO). (2006). Guidelines for the safe use of wastewater, excreta and greywater, volume 2: Wastewater use in agriculture. Geneva: World Health Organization (WHO). 